\title{
Aspectos comunicativos del cancionero inédito del siglo XVII RAE RM 6212
}

\author{
Pedro Aguilar SerRano \\ Universidad Nacional de Educación a Distancia (UNED) \\ pedroaguilarserrano@gmail.com
}

Recibido: $29 / 11 / 2012$

Aceptado: 23/01/2013

\begin{abstract}
Resumen
Tras el análisis del cancionero RAE RM 6212 (primer cuarto del siglo XVII) sabemos que los cancioneros hacían la función de las revistas escritas y audiovisuales de la actualidad. Eran fuentes de transmisión de ideologías, de los mensajes del poder y servían de cauce a las nuevas corrientes culturales y de pensamiento. Cumplían una función propagandística, al ser una herramienta codiciada por su popularidad y aceptación, y fueron utilizadas para perpetuar la memoria de quienes tenían el poder o incluso para propiciar la caída de quienes podían socavar el sistema. Aplicando el Análisis Transaccional a sus poemas hemos comprobado cómo el comportamiento de los personajes de los poemas obedece a unas normas de conducta que se ajustan a los diferentes estados precisados por Eric Berne al estudiar el comportamiento humano.
\end{abstract}

Palabras clave: Cancionero- Comunicación- Revistas- Propaganda- Kitsch.

\section{Communicative Aspects Unreleased Songbook Century XVII RAE RM 6212}

\begin{abstract}
After the analysis of the Songbook RAE RM 6212 (first quarter of the 17th century) we know that the songbooks were the magazines and audiovisual items of the present time. They were sources to transmit ideologies, messages of the power and used as a channel to the new cultural trends and thoughts. They fulfilled a role as propaganda, because of the fact that they were a greedy instrument for their popularity and acceptance, and also they were used to held in memory of the powerful people or even though to cause the fall of those who could undermine the system. When applying transactional analysis to his poems we have realized how the behavior of the characters in the poems is due to rules of conduct that adjust to different States specified by Eric Berne to study human behavior.
\end{abstract}

Keywords: Songbook, Communication, Magazines, Propaganda, Kitsch.

\section{Referencia normalizada}

AGUILAR SERRANO, Pedro (2013): “Aspectos comunicativos del cancionero inédito del siglo XVII RAE RM 6212". Estudios sobre el mensaje periodístico. Vol. 19, Núm. especial abril, págs.: 565-582. Madrid, Servicio de Publicaciones de la Universidad Complutense.

Sumario: 1. Introducción. 2. Cultura y comunicación en el Barroco. 3. La Agenda Setting. 4. Un siglo en crisis. 5. Literatura de masas, la anamorfosis y los productos kitsch. 6. Referencias biblográficas

\section{Introducción}

Los cancioneros o volúmenes de poesías varias, que se escribieron por miles entre los siglos XV y XVIII, y que en muy escaso número han sido editados y estudiados, son una importante fuente de comunicación desaprovechada, un tesoro informativo sobre el sentir y pensar de los españoles de una época, casi por descubrir. Sus páginas recogen todo aquello de lo que se hablaba en la calle, lo que sucedía en los barrios humildes y también lo que acontecía en la Corte. Lo allí escrito interesaba a todo el abanico social. 
La abundancia de textos y el escaso interés mostrado por la crítica a lo largo de la historia, al ser considerados los cancioneros obras menores, nos animó a acercarnos, desde la perspectiva de la comunicación, a estos libros que tanta aceptación tuvieron en su tiempo y tan poca en los últimos dos siglos. De ahí que centramos este trabajo en un cancionero inédito y por consiguiente poco conocido, por no decir casi desconocido, el signado con el número 6212 de la Real Academia Española (RAE), perteneciente a la colección de Antonio Rodríguez Moñino (RM).

Tras consultar algunos volúmenes de poesías varias, comprobamos que el 6212 era el manuscrito que más datos aportaba sobre la época y la manera de relacionarse, individual y colectivamente, de sus miembros. Era tal la variedad de temas que abordaba en sus poemas, lo ameno de la versificación; tales los aspectos históricos e informativos sobre la realidad de la España del XVII, que decidimos centrarnos en su estudio.

La fecha en la que fue recopilado este interesante ramillete de poemas no figura en el texto manuscrito, pero un primer acercamiento nos conduce hacia la primera mitad del siglo XVII, si nos atenemos a referencias y ausencias a diferentes personajes y sucesos históricos, entre otras la niñez de Felipe IV o la no mención del ajusticiamiento de Rodrigo Calderón (sobre el que se escribieron cientos de coplas), mientras sí registra el apresamiento previo de Pedro Franqueza, ambos compañeros de corruptelas en el gobierno de Felipe III.

\section{Cultura y comunicación en el Barroco}

A la hora de afrontar este trabajo, en el que caminan de la mano la literatura, el periodismo y la investigación histórica, fijamos varios objetivos. En primer lugar consideramos imprescindible definir, aunque fuera someramente, las características básicas del Renacimiento y del Barroco para ofrecer una concepción global de los usos y gustos comunicativos de aquellas épocas. Qué comparten y qué las diferencia. Hemos podido comprobar cómo un mismo suceso tiene un calado diferente en la sociedad del XVI que en la del XVII; son otros los intereses, las preocupaciones y los anhelos y por consiguiente es otra la manera de comunicar. No hay que olvidar que los cancioneros recogen poesía de distintas épocas y que en muchos casos, éstas son alteradas por el uso y la transmisión oral, e incluso por el propio recopilador que las ajusta a sus gustos y necesidades, y las de sus receptores, lo que nos aporta una valiosa información sobre qué interesa de un mismo suceso histórico o de un personaje, en según qué época, o cómo cambia la manera de comunicar los sentimientos amorosos a través de la escritura.

En este análisis de un texto manuscrito inédito, consideramos imprescindible comparar y contrastar las modalidades de comunicación en las clasificaciones de poemas dentro de nuestro cancionero. Para esta clasificación optamos por dividir los poemas según el tema a tratar, ya fuese de asunto amoroso, religioso, histórico-político, metafísico o satírico-burlesco. Enseguida nos dimos cuenta de que la división en apartados estancos es útil para el análisis pero no se ajusta plenamente a la realidad. En nuestro cancionero encontramos numerosos poemas dedicados a la muerte de Felipe II, un acontecimiento que conmocionó a la sociedad de la época, que movilizó a cien- 
tos de miles de personas en señal de duelo y que durante decenas de años fue recordado, celebrado y fue motivo de miles de poemas y escritos de todo tipo. Un suceso que teniendo un origen histórico claro, la muerte del Rey, es abordado en este cancionero desde una óptica religiosa unas veces, política otras y metafísica, las menos. Incluso los tres planos se abordan en un mismo poema; por tanto su clasificación no deja de ser aleatoria.

Al analizar los aspectos antes mencionados y profundizar en el estilo literario de los poemas del cancionero, obtenemos una más que interesante información sobre cómo eran los hombres y mujeres de la época, cuáles eran sus gustos y sus fobias, según la clase social a la que pertenecían. Todo ello nos ha obligado a inferir aspectos de la cultura y de los cambios de comportamiento social e individual entre Edad Media, Renacimiento y Barroco.

Al finalizar la Edad Media, y durante el Renacimiento y el Barroco, ya no había sólo un orador que se dirigía a un grupo presente en un mismo lugar, sino que los receptores también eran personas desperdigadas en el tiempo y en el espacio, menos sensibles a la retórica de grueso calado que a las reflexiones íntimas, y eso se nota a la hora de escribir poesía. El emisor entonces, como siempre, busca el asombro del receptor, la sorpresa, llamar su atención, de ahí que utilice técnicas, en lo que es un antecedente claro de la psicagogia de la atención, que nos recuerdan algunas empleadas en los medios audiovisuales de nuestro siglo XXI.

Como herencia de la cultura latina y medieval, en el Barroco se desarrollaron las condiciones de una cultura visual propicia al tratamiento analítico del texto, a la integración y a la contaminación de la imagen y la escritura dentro de un proceso general. Como asegura Gonzalo Abril: "Los jeroglíficos, emblemas, escenas mnemotécnicas, empresas, lemas, caligramas y otros muchos textos alegóricos de la época barroca, conforman una "cultura logoicónica" en la que se insertarán más tarde las páginas de prensa, los anuncios, el collage, el caligrama y las técnicas del montaje artístico vanguardista". (Abril, 2003: 97-98)

El Barroco recuperó la idea horaciana, presente en la Edad Media, de que todo aquello que entra por los ojos tiene más poder de conmover al espíritu que el lenguaje. Qué otro fin sino llamar la atención, y hacer partícipe al lector u oidor para que cale en él con más fuerza el mensaje, tiene esta adivinanza presente en el cancionero RAE RM 6212:

Un muerto fue en la tierra sepultado

y estando todo casi consumido

del tiempo vino a ser resucitado.

Después, sin culpa suya, fue traído

a ser entre dos peñas quebrantado,

pasó en forma de cielo combatido,

fue después en cordero y león junto,

¿qué es si cosa?, a todos los pregunto. (Poema 64 RAE RM 6212)

Una vez leído el poema, la referencia a Jesús de Nazaret parece clara, sin embargo, el autor añade bajo los versos anteriores, en una acotación hecha al margen, como esas soluciones a las adivinanzas y jeroglíficos que aparecen en los libros de pasa- 
tiempos, la siguiente frase: "Es el secreto el grano de trigo". No es lo que el espectador o lector pensaban. El autor juega con la percepción de la realidad, envía un mensaje subliminal contra todos aquellos que ponen en duda la resurrección de Jesús como hijo de Dios, principalmente los protestantes, y llama la atención para que el mensaje sea retenido el mayor tiempo posible usando un juego casi infantil.

Ejemplos como el anterior evidencian que durante el Barroco se avanzó mucho en el desarrollo de la tecnología de la percepción y de la imagen, casi siempre al servicio del poder político y religioso. Muchas de estas "afecciones" ya estaban presentes en la antigüedad y en la Edad Media latina. Entre ellas algunos manierismos formales, como son los poemas en los que no aparece una letra determinada en todo el texto, los poemas de figuras, los versos de cabo roto, la asíndeton o los paralelismos rematados al final del poema con una estrofa recopilatoria, etc... Estos y otros muchos recursos que caracterizan la literatura del XVII tienen abundante presencia en nuestro cancionero RAE RM 6212.

La contemporánea sociedad del espectáculo fue anticipada ya en la Edad Media y desarrollada en el Barroco, cuya inclinación a la espectacularidad se manifestó en expresiones tan dispares como las celebraciones festivas y los rituales públicos, las fachadas, los retablos, la dramaturgia, los enterramientos y sus túmulos o la magia. Se trataba de buscar ilusión en una sociedad desilusionada y de provocar el asombro, entre otros fines, para que se visualizara el poder: "Las prácticas de la publicidad y el consumo de nuestra época manifiestan esa misma ambigüedad: la marca nos invita a la fantasía y a la distinción, nos interpela en tanto que sujetos individuales con deseos, gustos y hasta caprichos propios, pero al mismo tiempo nos invita a una pertenencia colectiva". (Abril, 2003: 106)

Como a los grandes espectáculos barrocos, herederos de las más sencillas puestas en escena medievales de los autos sacramentales, por ejemplo, a la publicidad de hoy le corresponde proponernos modelos, incitarnos a desear ser, parecernos a otros e integrarnos en un grupo. No existe un colectivo sino que éste se crea entre la masa de receptores y según el éxito del efecto del propio anuncio.

En ese contexto, los cancioneros son un producto cultural destinado a satisfacer las necesidades comunicativas y de diversión de un público que consume cultura en grandes cantidades, porque tiene tiempo libre. Receptores de su mensaje que se divierten participando en juegos florales, disputas poéticas, comedias y recitales. Un público que recopila historias en verso y en prosa, bien para releerlas o para no olvidarlas y usarlas como entretenimiento en las reuniones de grupo. Obras que se ocupan de temas variados, lo mismo un cotilleo de palacio que una reflexión metafísica, y que están compuestas por auténticos genios de la literatura (Cervantes, Lope de Vega y Góngora están presentes en el RAE RM 6212) y también por meros aficionados, creadores de auténticos productos kitsch.

Este tipo de volúmenes eran el acomodo perfecto para aquellas poesías propiciadas por grupos determinados de poder que intentaban crear opinión entre el pueblo. Algunas eran auténticas obras de arte, como este soneto de Cervantes:

"¡Boto a Dios que me espanta esta grandeza

y que diera un doblón por describilla 
porque a quien no suspende y maravilla esta máquina insigne, esta grandeza [...]" (Poema 57 RAE RM 6212)

Y otras meros productos de consumo rápido:

Calmo lecciones tomaba de cantar de un gran maestro, en grande opinión estaba y para sacarle diestro estos puntos le enseñaba. A ur, re, mi, fa, sol, la, baja el la, Calmo ha subido, corrido el maestro está de que un error tan sabido le nació a Calmo del la. (Poema 118 RAE RM 6212)

\section{La Agenda Setting}

Los estudios sobre la agenda de la comunicación, Agenda-Setting o teoría del establecimiento periodístico de temas de discusión, a pesar de ser relativamente recientes, aportan un valor añadido al estudio de la influencia de los diferentes medios en la opinión pública a lo largo del tiempo.

Según esta teoría, los medios masivos, los cancioneros con éxito se reeditaban durante decenas de años y los compuestos por aficionados se cuentan por decenas de millares, graduarían la importancia de la información que se va a difundir, dándole un orden de prioridad para obtener una mayor audiencia a determinados asuntos. De esta manera los medios y los poderes que los controlan serían quienes marcarían la agenda de opinión del público excluyendo o potenciando determinados temas o asuntos. Su influencia no incidiría tanto, parafraseando la famosa frase de Cohen, en decirle a la gente qué tiene que pensar sino sobre qué tiene que pensar.

En el siglo XVII fueron muchos los esfuerzos surgidos desde el poder religioso para que el pueblo debatiese de asuntos tan poco populares como la concepción inmaculada o no de María, sobre la que se escribieron miles de tratados y poemas y de la que se acabó hablando en las tabernas. La intención, al despertar debates de este calado, no era otra que consolidar la hegemonía de dos órdenes religiosas: jesuitas y franciscanos, frente a la pujanza de los dominicos. Los poemas al nacimiento de Cristo de una mujer virgen y a su resurrección una vez muerto, pueblan los cancioneros, sin duda por ser estos asuntos los más cuestionados por las corrientes religiosas nacidas en el centro de Europa. A nivel político no es baladí que se multipliquen los poemas que cantan a Carlos I, Felipe II o los Reyes Católicos, ejemplos de buen gobierno y garantes de una sociedad fundamentada en la monarquía y el predominio de la aristocracia. Ejemplos a seguir, iconos del sistema, en una España en crisis, económica y de valores, como era la de comienzos del siglo XVII.

Ya a principios del siglo XX, Walter Lippmann señala en su obra Public Opinion que los medios de comunicación son la fuente principal de creación de imágenes del mundo exterior en nuestras mentes. Con esto se destaca que el mundo que nos rodea es demasiado grande como para poder acceder a la información de primera mano con recursos propios. Por ello, necesitamos medios que nos cuenten "cómo es ese mundo 
al que no tenemos acceso, con el riesgo de que nuestras mentes reproduzcan un mundo distinto al real, ya que éste está fuera de nuestro alcance" (Rodríguez Díaz, 2004: 28). Los cancioneros eran, junto a otros productos como los pliegos, libelos, hojas sueltas, etc... los medios de comunicación del XVII, medios en muchos casos masivos que corrían de mano en mano, de rincón en rincón de la ciudad y de casa en casa portando mensajes.

Gerald Miller afirma que la comunicación de masas reúne las siguientes notas:

a) Para su producción se necesitan un conjunto de profesionales en alta tecnología que, juntos, conforman una organización;

b) El número de «agentes» o «co-productores» a los que puede llegar la comunicación masiva o colectiva es muy grande, pero el grado de relación personal puede ser inexistente o muy reducido entre ellos;

c) El grado de proximidad física entre los emisores de los mensajes y la audiencia es muy bajo;

d) Los canales sensoriales disponibles son mínimos para recibir el mensaje;

e) La inmediatez en la información de retorno es muy diferida. Estas notas no aparecen a la vez y bajo el mismo aspecto en la comunicación interpersonal, de grupos y en las organizaciones. (Miller, 1978: 141-185. En Valbuena, 1998: 73).

En los años sesenta otros estudiosos introducen la importancia, el papel y la presión que los grupos empresariales o fuentes de poder desempeñan para que la selección de ciertos temas sean propicios para publicarse o aparecer de forma destacada en los medios de comunicación. Pero será McCombs (En Valbuena, 1978: 76) quien marque el segundo nivel de la Agenda-Setting que hace mención a las imágenes y las perspectivas que entran en el plano subjetivo y de la opinión, que tiene que ver con cómo se produce la transferencia de prioridades y el énfasis otorgado a cada uno de los temas.

Sin entrar en los métodos de análisis de contenido utilizados para llevar a cabo la Agenda-Setting, el procedimiento consiste en realizar mediciones diferentes del tema o temas objeto de estudio, contabilizando el número de artículos ubicados, el número de páginas o columnas que ocupan y la ubicación que tienen dentro del medio, todo ello en un periodo de tiempo. De esta manera conocemos la importancia que dicho tema ocupa en el medio. Si a esto se añaden encuestas realizadas a la población y se le pregunta, por ejemplo "¿Cuál es el problema más importante al que tiene que hacer frene este país?", analizando y cotejando las respuestas con las informaciones se puede ver qué relación existe entre ambas agendas: la de los medios y la del público". (Valbuena, 1998: 555-570).

Nuestro cancionero hace hincapié en aquellos asuntos que interesan a un determinado grupo, y recoge ramilletes de poemas temáticos (Loas a María la madre de Dios como madre virgen, exaltación de personajes históricos y batallas victoriosas, difusión de los postulados franciscanos y de sus santos y frailes más populares, respeto a la reglas marcadas por la Contrarreforma, ataque a quienes ponen en peligro el orden social con sus devaneos y corruptelas, etc...). El poema será pues, de acuerdo con la metodología del Análisis de Contenido, la unidad de registro. En los diversos poe- 
mas, los autores defienden tesis muy diversas sobre asuntos muy distintos. El poder político quiere crear una corriente de pensamiento sobre los asuntos controvertidos.

$\mathrm{Al}$ aplicar los métodos de la Agenda-Setting a los poemas de nuestro cancionero RAE RM 6212 podemos sustentar la hipótesis, planteada al comienzo de este trabajo, de que los cancioneros o volúmenes de poesías varias son una esencial fuente de comunicación e información sobre el sentir y pensar de los hombres y mujeres que vivieron en la España de la época en que fueron escritos. Por lo allí reflejado sabemos qué interesaba y preocupaba a todo el abanico social de la primera mitad del siglo XVII, quiénes eran considerados héroes y quiénes villanos y por qué; de qué se burlaba la sociedad, cómo amaba y cuáles eran sus ambiciones y desengaños.

Leyendo las obras contenidas en nuestro cancionero podemos entender mejor a los españoles de aquella época. Extraigamos un ejemplo, en lo referente al amor, la pretensión del poeta barroco al loar a una dama ya no es otra, en la mayoría de los casos, que conseguir la consumación carnal. El amor se hace carne y ya no le vale al amantepoeta con ver a la amada y extasiarse con su imagen, quiere tocarla, poseerla y consumar el amor. De manera que se indigna y enfada cuando no es correspondido y protesta y ataca ofuscado en sus versos:

Siempre deseo tu gusto

y mi disgusto pretendes,

pues yo espero que algún día

pagarás lo que me debes,

que no hay para qué tener

valentías de mujeres,

pues lo que guardan treinta años

en media hora se pierde. (Poema 5 RAE RM 6212)

La mujer, aunque sigue ocupando los escalones más bajos de la escala social, adquiere un papel relevante en el juego amoroso. Ella también exige, se baja del pedestal al que la subieron los poetas del XV y del XVI y se convierte en una pieza activa de la sociedad y por ende del juego amoroso. De ahí que en nuestro cancionero aparezcan poemas puestos en boca de mujer en los que la dama se queja de la impotencia del varón y de los celos infundados de su marido.

Mosaico de una realidad, los cancioneros son pues una fuente comunicativa esencial para quienes, siglos después, queremos acercarnos a esa apasionante época de nuestra historia. Y en ese acercamiento nos encontramos con que el Barroco es la antesala de la Modernidad. El carácter inestable, cambiante, polidimensionado, superficial a la vez que enrevesado del Barroco, está presente hoy, en el siglo XXI, en todo el ámbito social y cultural.

\section{Un siglo en crisis}

Los cancioneros y los volúmenes de poesías varias son también algunos de los principales medios de información del siglo XVII, en ocasiones no inmediata, pero en otras acogieron poemas de una inmediatez evidente como es el caso del apresamiento del ministro de Hacienda Pedro Franqueza (Poemas 17, 18, 19 y 20 del RAE RM 6212) o la peste de 1599 (poema 131). Por los datos que acumula, podríamos deno- 
minar a los cancioneros como una pequeña "hemeroteca" que en ocasiones hace las veces de las revistas escritas y audiovisuales de nuestros días, no exentas de un cierto tono amarillista.

Los cancioneros cumplen asimismo una función propagandística, son herramientas codiciadas por su popularidad y utilizadas para perpetuar la memoria de grupos determinados, congregaciones o de quienes tienen el poder o incluso para propiciar la caída de quienes con sus abusos podían socavar el sistema, un sistema anclado en la monarquía, el catolicismo y la oligarquía.

El Barroco es un siglo en crisis, una crisis que va más allá de la economía e incide en el ámbito social, cultural y en el sistema de valores. El Imperio se desmorona, hace aguas y con él están a punto de derrumbarse los pilares sobre los que se sustenta. El desánimo y el desengaño cunden entre los españoles y el poder reacciona, busca sus estrategias para levantar la moral del pueblo y conducir sus sentimientos y acciones por un camino que siempre corre paralelo a los intereses de la oligarquía que tiene en el Rey a su principal valedor. El monarca es en el Barroco el garante del sistema, en él confía el pueblo y a él deben su posición los poderosos. La Iglesia juega un papel central en la Política del Rey.

En concreto el cancionero RAE RM 6212, escrito por una persona muy cercana a la orden franciscana, incluso miembro de ella, ensalza las figuras del cardenal Cisneros, de san Antonio Abad o del hijo de la princesa de Éboli, González de Mendoza, reconocidos franciscanos cuyas obras son cantadas y loadas por todo el abanico social.

Aplicando tanto el Análisis Transaccional como el modelo de las etapas del amor de Horton, hemos podido corroborar con un método científico cómo el comportamiento de los personajes de los poemas de este cancionero obedece a unas normas de conducta perfectamente delimitadas que se ajustan a los diferentes estados precisados por Eric Berne al estudiar el comportamiento humano y su posterior reflejo en el cine y la literatura. Veamos como ejemplo el poema 22 del RAE RM 6212 que está dedicado a uno de los personajes antes citados, Francisco Jiménez de Cisneros:

Romance del illustrísimo don frai Francisco Jiménez en la batalla de Maçalquivir

Con mucha jente española

sale de la gran Toledo

el ynbicto cardenal

frai Francisco de Cisneros.

Sobre la humilde capilla

y debajo del capelo

lleua la real corona

del gran Filipo el primero.

Llegó a la ciudad de Orán

$\mathrm{y}$ ante los muros soberbios

les dice el cristiano Marte

a sus famosos guereros:

"Al arma, al arma, fuego, fuego,

que es nuestra por la fe uencer muriendo".

Mientras duró la batalla

al santo arçobispo bieron 
en Maçalquibir orando

de san Miguel en el tenplo.

Como otro Moises estaba

en fabor de los hebreos,

y contra los de Amalec

pidiendo vitoria al çielo.

Cuatro oras detubo al sol

en medio de su hemisferio,

mientras que los españoles

al africano uençieron.

En estos versos vemos la clara exaltación de la figura de un personaje histórico capaz de sucesos sobrenaturales, en este caso Francisco Jiménez de Cisneros que, curiosamente, murió en el año 1517, es decir, aproximadamente un siglo antes de la confección, según nuestros cálculos, de este cancionero. Este dato nos lleva a preguntarnos: ¿Por qué se copia en el XVII una "noticia” de comienzos del XVI? ¿Por qué sacar a la luz el intento cisneriano de conquistar África? ¿Serían este tipo de poemas un acicate, una manera de recordar glorias pasadas que sirvieran para estimular a una sociedad en horas bajas o hay algo más? Cisneros pertenece a la historia de lo que algunos estudiosos llaman la Prerreforma y que el cardenal materializó a lo largo de su vida con fundaciones, lucha contra los rebeldes de la fe, constitución de sínodos, favores administrativos a los hombres de religión y una seria preocupación por enseñar la religión a los niños (publicó un catecismo) y devolver la cordura a los malos usos de los clérigos y sacerdotes (editó documentos contra los sacerdotes concubinarios).

Fue en él (Cisneros) preocupación constante mejorar el comportamiento de sacerdotes y religiosos. Todos sus esfuerzos de reforma son un testimonio de ello, y mucho más elocuentes aun son las fundaciones mediante las cuales quiso resolver el problema del reclutamiento, de la selección. La creación de la Universidad de Alcalá no fue sino la instalación de un organismo completo de enseñanza eclesiástica: elemental, media y superior. (Bataillon, 1979: 10)

Cisneros no sólo representa el espíritu de la Contrarreforma, que le sucedería en el tiempo, es también uno de los franciscanos más ilustres, y ya hemos dicho que la persona que recopila este manuscrito deja entrever su cercanía, o su pertenencia, a esta orden. Cisneros se propuso desde su llegada al arzobispado de Toledo aplicar con vehemencia la pobreza franciscana, hasta el punto de que, debido a las críticas de quienes le rodeaban, todos ellos sacerdotes, el Papa tuvo que llamarle la atención por su exceso de celo y Cisneros volcó entonces su entusiasmo por la regla en las órdenes monásticas, a las que consideraba verdadero ejemplo de religiosidad. ¿No será pues este poema un intento por parte de una facción de la Iglesia de aupar la Contrarreforma, recuperando así la figura de un reformista ortodoxo y conservador como fue Cisneros?

No podemos olvidar que las biografías ocuparon un porcentaje muy importante de las ediciones de libros que se publicaron en España durante el siglo XVII, como puede verse en los catálogos de la época. No es de extrañar, cuando se trata de buscar un vehículo eficaz de educación popular y un vínculo entre el autor y el receptor, o como 
apuntan algunos estudios, de configuración moral y política, cuando ésta se dirige, como sucede ya en el Barroco, a un público anónimo y numeroso.

Ahondando en este asunto, Gonzalo Abril aporta una interesante teoría que relaciona acertadamente el empleo y difusión de una marca en la publicidad moderna, icono que alegóricamente identifique al producto, con los emblemas, empresas y signos usados en el Renacimiento y el Barroco. Recuperar personajes, hazañas, gestos y sucesos que tuvieron una clara aceptación social en una época, no deja de ser una manera de crear una marca publicitaria que represente de manera alegórica a la monarquía o incluso al Estado o a una orden religiosa, en momentos de baja aceptación social, de crisis, como sucede en el poema 119 del RAE RM 6212 dedicado al rey Fernando el Católico. Esta relación alegórica es aún más evidente cuando se piensa en la marca, no como signo de la mercancía, sino como índice de la identidad de quien la adquiere y exhibe, de la pertenencia al grupo real o imaginario de quienes están marcados por ella. "Las dos funciones de la marca son interpretadas como correspondientes a dos momentos del capitalismo: en el capitalismo de producción la marca lo es del producto, garantizando la propiedad del fabricante; en el capitalismo de consumo, la marca sirve para marcar a los consumidores, para clasificarlos y jerarquizarlos. En este segundo caso se advierte aún más claramente la semejanza de la marca con aquellos símbolos del Barroco. (Abril, 2003: 106)

El poema 22 es un texto que con toda seguridad formó parte de la propaganda franciscana sostenida durante la práctica totalidad del siglo XVII, a favor de la elevación a los altares de Francisco Jiménez de Cisneros, en un proceso iniciado en 1530 con la causa de beatificación y que no pudo concluirse satisfactoriamente.

Si aplicamos el Análisis Estructural al personaje de Cisneros, según nos lo presenta el autor del poema, vemos que el estado del ego que predomina en él es el de Padre Protector, especialmente manifestado en los últimos versos: "Cuatro horas detuvo el sol/ en medio de su hemisferio/ mientras que los españoles/ al africano vencieron". Su comportamiento se vuelve Adulto, cuando apoya las armas, "Al arma, al arma, fuego, fuego...", cuando el narrador quiere hacer hincapié en su calidad no de hombre de religión sino de guerra.

Esa actitud se convierte en la de Niño natural cuando se postra ante Dios, y reza sumiso pidiendo la victoria al único "ser" que siente por encima de él. Es decir, Cisneros es un Padre Nutricio como cardenal protector de almas, Adulto como hombre de guerra y Niño Adaptado en su relación con Dios. Como vemos, el Análisis Transaccional nos ayuda a definir la intención del poeta en la caracterización del personaje. Cisneros recibe Caricias positivas: "invicto", "santo", "otro Moisés" por parte del narrador. La estructura del tiempo es de plena Actividad y en cuanto al rol, está claro que es de Salvador.

Hay tres claras transacciones en el poema. El poeta manifiesta una transacción de admiración al cardenal, al crear una obra propagandística: "Con mucha gente española/ sale de la gran Toledo/ el invicto cardenal/ fray Francisco de Cisneros". En la admiración, el Adulto examina a la otra persona y le dice al Niño que siga adelante. La admiración surge porque el Niño se queda maravillado ante la presencia, fuerza y energía del Padre real. Hay quienes aceptan la admiración y la transforman en una experien- 
cia valiosa, porque saben que la gente necesita modelos de comportamiento, como es el caso. (Valbuena, 2006: 123)

En los versos: "Al arma, al arma, fuego, fuego/ que es nuestra por la fe vencer muriendo", el cardenal manifiesta una transacción complementaria Padre-Adulto, apoyando a otra persona, en este caso a las tropas, para que tomen una decisión. Es lo que se llama una transacción de Apoyo.

En su actitud ante Dios, rezando, Cisneros adopta una clara actitud de Súplica, transacción complementaria Niño-Adulto. Pide ayuda para salir victorioso en la batalla.

El Análisis Transaccional aplicado a este poema ahonda en lo que acabamos de decir. Observamos que hay un narrador-poeta que se sitúa en un plano Adulto y que, tras analizar una situación extrema, la epidemia de peste, dice lo que conviene hacer al resto de la sociedad: "Alzad los ojos al cielo", "haced capilla formada", "oficiad por los difuntos", "convidad para este entierro/ a los que en la corte hubiere", "Vengan los santos del cielo", etc.... Mantiene una actitud YO ESTOY MAL- TÚ ESTÁS MAL, dentro de un estado emocional de Miedo y el rol que desempeña es el de Salvador.

\section{Literatura de masas, la anamorfosis y los productos kitsch}

Nuestro cancionero nos informa también de otros aspectos, como la realidad vivida por los Tercios españoles, de donde volvieron miles de soldados rompidos. Españoles que dieron lo mejor de su juventud por el Imperio y por la religión, y regresaron, como siglos después lo harían los soldados de Cuba o los marines de Vietnam, para ser ignorados, cuando no despreciados por sus vecinos y por su país, y formaron parte de la legión de pícaros y menesterosos que poblaban las ciudades españolas.

Subí murallas, destruí ciudades,

maté enemigos, bravos hechos hice

a mi nombre ganando eternidades,

$y$ al fin perezco en soledad y males. (Poema 4 RAE RM 6212)

El hacinamiento de hombres y mujeres en las ciudades trajo como consecuencia, no sólo la picaresca y los menesterosos, sino la elaboración de productos sociales y culturales destinados a un público indeterminado, que compra sólo aquello que le gusta e interesa o que le divierte y entretiene. Nace así la cultura de masas y al socaire los primeros productos kitsch fruto de esa bipolarización de la cultura por razones sociales e históricas que obliga a una pluralidad de mensajes.

El Cancionero RAE RM 6212 se hace eco de poemas destinados a los dos tipos de consumidores que conviven en la sociedad, el hermético y elitista y el popular y abierto. El gran público consumía uno, pero le gustaba saber del otro, aunque enseguida vemos cómo prima en nuestro recopilador el gusto por lo fácil y popular, en definitiva lo que podemos definir como poemas de la subcultura. Los productores de estas "mercancías", hoy como entonces, usan los resortes de este tipo de cultura para configurar tipos, formar mentalidades y agrupar masas ideológicamente.

Si en el siglo XXI hay una preeminencia del mundo de la imagen y de la percepción visual, si este siglo y el anterior se caracterizan por una ruptura con los lenguajes tradicionales, hemos podido ver en nuestro cancionero que esa intencionalidad ya 
se había extendido en el Barroco. La búsqueda de la complicidad del receptor, el uso de la persuasión y la admiración para traer al público es una constante en la cultura y el espectáculo barrocos. En un siglo como el XVII en el que hay un reiterado elogio de la dificultad, en el que la literatura es sobre todo conceptual, es normal que abunden las contradicciones elaboradas, que no dejan de ser puros conceptos, como la popular EVA, mujer que incitó a pecar al hombre y causó la "perdición" de la humanidad, frente a AVE, calificativo con las mismas letras dispuestas en otro orden, que acompaña a María, la mujer que encarna la salvación:

Del pecho del ave

más excelente, salió el manjar blanco

que veis presente.

El ave es aquella

que dio tan gran vuelo,

que al autor del cielo

lo parió doncella.

Y el pecho della,

puro excelente,

salió el manjar blanco

que veis presente. (Anónimo, Cancionero sevillano de Lisboa, Labrador, 2003: 229)

En un mismo poema se concentran pues las explicaciones de tres misterios en los que se fundamenta la Iglesia católica: la encarnación del hijo de Dios, la virginidad de María y la transformación de Jesús en Sacramento, "manjar blanco". Todo ello envolviendo la explicación de María como AVE e insinuando la presencia del Espíritu Santo y lo que éste encierra, el misterio de la Trinidad. Juego conceptista, simple elaboración poética pero destinada a un fin, unas veces en un mero artificio poético, otras, no exenta de paradojas.

Estas contradicciones suelen servir muy bien al espíritu pedagógico de la época, usadas de manera clara e intencionada por los poderes fácticos. Para algunos sectores sociales, cuanto más difícil es la enseñanza y más oscura la estrategia, más eficaz es el resultado, se afianza con más fuerza entre quien recoge el mensaje. "De ver las cosas muy claras se engendra cierto fastidio, con que se viene a perder la atención y así se leerá un estudiante cuatro hojas de un libro, que por ser claro y de cosas ordinarias no atiende a lo que lee. Mas si es dificultoso y extraordinario su estilo, esto propio lo incita a que trabaje por entendello, que naturalmente somos inclinados a entender y saber y un contrario con otro se esfuerza, así con la dificultad crece el apetito de saber" (Carballo, en Maravall, 1996: 448)

Es decir, que cierta dificultad en la difusión de un mensaje es bien aceptado por un sector de los consumidores masivos de cultura, de ahí que en el XVII, aun en cancioneros como el que nos ocupa, estén presentes este tipo de juegos conceptuales. La dificultad ayuda a fijar la atención y conseguir que el mensaje permanezca durante más tiempo retenido por el receptor, por eso los divulgadores de los dogmas religiosos usan frecuentemente este recurso, unido a la simple exposición mediante performances o imágenes parecidas, el caso es llegar al abanico más amplio posible de la so- 
ciedad. "Una doctrina que capte y quede impresa, una obra de arte que introduzca en su mundo al público y le mueva, un poder político que espante y se imponga, todo ello y tantas otras manifestaciones más de la vida social del XVII requieren oscuridad, la cual refuerza la suspensión y se traduce en dificultad". (Maravall, 1996: 449)

La mayoría de la literatura debe leerse con una doble mirada: la aparente y la que se esconde detrás de los símbolos. Leer es descubrir lo que está oculto "pero enigmáticamente revelado en el signo" (R. de la Flor, 2002: 18). Ahí encontraremos el mensaje que quiere trasladar el poeta y que obedece a objetivos religiosos, políticos, educativos o simplemente de evasión. Las formas de lo anagramático son muchas y son el "pasto ideal del alma", como decía Gracián. Todo ello forma parte de un conjunto de manifestaciones artísticas en las que están presentes la pintura, la escultura, las ceremonias religiosas, las fiestas públicas o los catafalcos.

En este ramillete se incluye también la poesía experimental que toma elementos de los avances de la ciencia o de la intuición, de lo que serán sus premisas básicas en cuanto a supresión de antiguas suposiciones, como asegura Fernando R. de la Flor: "La inestabilidad, la dificultad y el enigma que envuelve todo demandan unas fórmulas creativas que acompañen la nueva percepción de que el lugar de la cultura es el lugar también de lo arduo, de lo oscuro, de lo difícil y aun de lo prodigioso". (R. de la Flor, 2002: 352)

En otras ocasiones, el poeta se conforma con envolver su mensaje con un juego de ingenio: un pie, un verso sencillo, que sirve para construir un poema. Esta técnica estaba ya presente en las primeras manifestaciones de la lírica popular no sólo castellana (jarcha, villancico) sino universal. A veces el pie no es de un solo verso sino de cuatro:

No hizo pecado Adán.

Cristo no resucitó.

San Pedro no lo negó.

Ni lo bautizó San Juan.

Cuatro pies, presentados a modo de estrofa, que se ofrecen al desarrollo en el poema 34 del RAE RM 6212 para dejar claros al público o lector cuatro sucesos de la vida de Cristo. Para ello no duda el autor en forzar en demasía el sentido de los versos, lo que indica la mediana pericia literaria de su autor. Lo importante es calzar el pie, en esta ocasión plagado de paradojas.

Como de su bondad pía

por su muerte bien se vio

no faltar la profecía,

pues ni al cuarto y quinto día

Cristo no resucitó. (Poema 34, RAE RM 6212)

Como el anterior, otros 13 textos de escaso valor literario forman parte de estos juegos literarios, de estos poemas de temática religiosa que tan aceptados fueron por los hombres y mujeres del XVII. Los pies se repiten continuamente, de ahí que existan glosas diferentes para un mismo pie. El poema 35 de nuestro cancionero, que en el manuscrito figura sin pie inicial y que se repite, ya con él, en el poema 46, desarrolla el mismo lema que el último de los propuestos en el poema 35: "Ni le bautizó San Juan". 
Es interesante ver de qué manera resuelve cada uno de los autores una misma manda. Este ejemplo nos puede servir para corroborar de manera directa cómo este volumen de poesías varias recoge textos con una enorme diferencia de estilo y de calidad literaria.

En el poema 35 su autor afronta de esta manera el pie: "Ni lo bautizó san Juan":

Si Cristo se bautizó

por Joan sin haber errado,

dirás pues Dios no á pecado

del yerro en que Adán cayó

pretendió aberse labado.

Pero agraviase su nombre,

que si a Cristo dado le han

el bautismo y su renombre,

ni por eso se hizo hombre

ni le bautizó San Joan.

Estamos ante un poema culto, que entraña cierta dificultad para ser comprendido, en el que su autor juega hábilmente con uno de los temas usados en las polémicas y debates religiosos: el yerro del bautismo de Cristo: ¿Por qué alguien que es Dios tiene que bautizarse? El autor se sirve del pie para cerrar una serie de contradicciones, de frases condicionales, con las que insiste en que fue el propio Dios el que quiso que su hijo fuera bautizado por cuestiones más complejas que el mero yerro de Adán, y que tienen que ver con su desdoblamiento como hombre y, como tal, su comportamiento tiene que ser humano y ejemplar.

Sin embargo cuán diferente es el poema repetido en el 46:

Ban caminando al Jordán

Joan y Cristo mano a mano

y las palabras que an

son remedio soberano

para los hijos de Adán.

Joan a Cristo preguntó:

“¿É de echar el agua yo"?

Dijo sí y echola listo

que hasta mandallo Cristo

san Joan no le bautizó.

Nada que ver la calidad de uno y otro poemas. El autor de este último va a lo fácil, reproduce un diálogo entre Cristo y Juan y cuela el pie forzado, de la manera más simple, propia de la pericia de cualquier adolescente medianamente leído. Está claro, a nuestro recopilador le importa menos la calidad de los textos que el tema que desarrollan, e incluso que la aceptación social que tengan o puedan tener, lo importante es el mensaje, el fin propagandístico. "¿Qué bien están los jeroglíficos en las fiestas de los santos!" exclamó Lope de Vega en una justa poética hecha en Madrid a San Isidro.

Prosigamos con los ejemplos de anamorfosis, juegos de perspectiva, poesía de artificio presente en el RAE RM 6212. Otro de los grupos importantes lo forman los que se basan en la repetición, no ya de versos en forma de pie, sino de letras y sílabas, y 
la de aquellos que no las reiteran sino que las eliminan. Dentro de este grupo, De Cózar incluye los tautogramas, lipogramas, los serpentinos, los ecos, jitanjáforas, paranomasias y el artificio que algunos llaman "versos de cabo roto" donde podemos incluir el poema 17 de nuestro cancionero:

Biba nuestro rei milaque vive tanrectameny hace tantas diligenpor descubrir la berdápues saca de Prado pay franquesas de Franque-

Este poema no es religioso, está dedicado como vemos a un asunto político ya mencionado como es el de la corrupción de los validos y sus secuaces. El poeta elimina adrede la última sílaba que el compilador sustituye por un guión, para buscar la complicidad del receptor. Es él quien debe terminar el poema con su ingenio, lo que le obliga a aprenderse bien y repetir, aunque sea mentalmente, el contenido del poema. De nuevo una impecable argucia didáctica.

Similar es el poema 86, un juego muy del gusto de la época. Un soneto en el que se sustituye la última sílaba de la palabra final del verso por una "x", una incógnita que cada uno rellena como quiere, en ese juego participativo del público que se presta a la interpretación erótica o escatológica, según el caso.

Cuando ella hizo primera, hice yo flux

y entonces trabajaba con mi box,

más quitese ya allá, señora, ox,

que huele ya mui mal su almoradux.

Yo me acuerdo cuando ella decía ax

mas ya se traga entero el mayor pex

y no hay quien de harta leña a su hornix.

Entreveladas alusiones a los órganos genitales de la dama y a su afición por los placeres sexuales y a la falta de higiene, que a buen seguro levantaban la risa fácil del espectador, en una fiesta privada o en un acto público, sobre un escenario. Existen varios ejemplos en este siglo del empleo de esta terminación en $-\mathrm{x}$, usada en poemas eróticos y festivos por autores como Góngora, o en poemas anónimos, como este recogido en el Cancionero sevillano de Lisboa:

Dungandux, dungandux, mozuelas con el dungandux.

Mozas si os queréis olgar

con un dungandux que yo tengo,

él es gordo y él es luengo,

y en esto no hay que dudar;

y si lo queréis provar

veislo aquí, sacaldo a luz:

dungandux, dungandux,

mozuelas con el dungandux. (Labrador, 2003: 53) 
A otro nivel, dentro de los artificios, en esta ocasión de repetición, están el poema 30:

De dolor en dolor, de llanto en llanto,

de un mal en otro mal va mi partido,

de un muy perdido, boi en más perdido

de un espanto de amor, en otro espanto.

Y el poema 66:

No ai cruz sin gloria ninguna

ni con cruz eterno llanto,

santidad y cruz es una,

no ai cruz que no tenga santo

ni santo sin cruz ninguna.

Aquí hay calidad literaria, juego conceptista, pero en manos de un gran creador.

También mencionamos con anterioridad otro de los juegos de perspectiva preferidos en el Barroco, los llamados poemas en eco, presentes en el cancionero con los números 31,32 y 89 :

Es para todos la Fortuna una

sin que aproveche en su balanza lanza

ni de los reyes la manada nada. (Poema 31 RAE RM 6212)

Estas composiciones, no exentas de complejidad y artificio poético, fueron muy practicadas por la mayoría de los poetas del siglo de Oro, y según la pericia del autor así era la calidad de los versos. Por lo general eran uno de los entretenimientos preferidos en las justas poéticas y su presencia en los cancioneros de la época es constante. Uno de los más afamados creadores de poesía en eco fue Quevedo, como podemos ver en este soneto:

Es el amor, según abrasa, brasa;

en nieve a veces, puro hielo, hielo;

es a quien pedir yo consuelo, suelo;

y saco poco de su escasa, casa.

Es un ardor que a quien traspasa, pasa;

y como yo a veces pasélo, sélo;

es un pleito do no hay apelo, pelo;

es del demonio que la amasa, masa.

Tirano a quien el cielo inspira, ira;

un ardor que si no se amata, mata;

gozo, primero que cumplido, ido.

Flechero que al que se retira, tira;

cadena fuerte que aun de plata, ata;

y mal que ha muchos a tejido, nido. (Quevedo, 1981: 321)

En los poetas vanguardistas de comienzos del siglo XX, y en muchos de los poetas urbanos de finales del siglo pasado, este tipo de composiciones tuvieron una gran aceptación. 
Por último vamos a referirnos a los acrósticos, a los que De Cózar otorga un valor especial, sobre todo aquellos que ocultan la autoría de una obra: "Sería preciso una investigación a fondo del acróstico y de su sentido a lo largo de los diversos períodos para determinar de qué manera puede ser considerado un simple juego literario, un artificio didáctico (en relación con los alfabéticos) y nemotécnico, o una fórmula de autoría en clave". (De Cózar, 1993: 318)

El acróstico más frecuente es el que se centra en las letras, pero los hay también de sílabas. Dentro de este grupo podríamos incluir nuestro poema 33 que, gracias a una filigrana de su autor, nos permite leer el verso completo o sólo hasta la pausa, que cae en la tercera sílaba, y de las dos maneras aporta significado:

Truéquense, ya fenescan tristemente

los trajes, los arreos y hermosura, en lutos, en ceniza y desventura, en llanto y en dolor grave y doliente.

Pues pudo el segador fiero, inclemente, ser quebranto de la humana compostura, dar tales en la real figura ultrajes con la española gente.

Caió Filipo, caiga en todo el suelo segundo mar de lágrimas corriente, anegue el pozo de ansia un mar profundo, del mundo pues llevó para sí el cielo.

Algunos estudiosos incluyen estos textos dentro del grupo de artificios que se conocen como poemas combinatorios correlativos, frecuentes en la Edad Media y que, en algunos casos deben leerse por columnas, como es el caso anterior, con la salvedad de que la columna de la derecha no tiene sentido sin la izquierda, mientras que ésta lo tiene por sí misma.

Lo que queda demostrado es que la preeminencia de la percepción visual que caracteriza al arte de los siglos XX y XXI, esa ruptura con los lenguajes tradicionales, ya está en el Barroco, como podemos comprobar gracias al manuscrito RAE RM 6212. Ese empeño en tomar la palabra como signo, como sonido o forma visual con valor en sí misma, más allá de su significado, tan propio de nuestra época, estaba presente en nuestros cancioneros y por ende, en todo el abanico de manifestaciones literarias del XVII. Esa es la conclusión que podemos extraer del análisis de este ramillete de poemas basados en las distintas modalidades de anamorfosis, que nos afirman en la consideración de los cancioneros como una fuente de comunicación inestimable y al Barroco como la antesala artística y comunicativa de la Modernidad.

\section{Referencias bibliográficas}

ABRIL CURTO, Gonzalo (2003): Presunciones II. Ensayo sobre comunicación y cultura. Valladolid, Junta de Comunidades de Castilla y León.

BATAILlON, Marcel (1979): Erasmo y España. México, Fondo de Cultura Económica. 
BOUZA, Fernando (1998): Imagen y propaganda. Capitulos de la historia cultural del reinado de Felipe II. Madrid, Akal.

CRIESZ, Ludwig (1973): Fenomenología del kitsch. Barcelona, Tusquets.

CURTIUS, Ernest Robert (1981): Literatura europea y Edad Media latina. México, Fondo de Cultura Económica.

DE CÓZAR, Rafael (1991): Poesía e imagen. Formas dificiles del ingenio literario. Sevilla, Carro de Nieve.

GRACIÁN, Baltasar (1974): Agudeza y arte de ingenio. Madrid, Espasa Calpe.

LABRADOR HERRAIZ, José Julián y DIFRANCO, Ralph (2003): Cancionero sevillano de Lisboa. Sevilla, Universidad de Sevilla

LIPPMANN, Walter (1997): Public Opinion. New Cork, Free Press Paperlacks.

MARAVALL, José Antonio (1996): La cultura del Barroco. Barcelona, Ariel.

MILLER, Gerald (1978): Interpersonal Communication en BOOK CASANDRA: Human Communication: Principles, Concepts and Skills. New York, ST. Martin Press.

RODRÍGUEZ DÍAZ, Raquel (2004): Teoría de la Agenda Setting. Aplicación a la enseñanza universitaria. Madrid, Observatorio Europeo de Tendencias Sociales.

ROGER DE LA FLOR, Fernando (2002): Barroco. Representación e ideología en el mundo hispánico (1580-1680). Madrid, Cátedra.

VALBUENA DE LA FUENTE, Felicísimo (1979): La comunicación y sus clases. Aplicaciones a diversos campos de la actividad humana. Zaragoza, Edelvives.

VALBUENA DE LA FUENTE, Felicísimo (1998): Teoría General de la Información. Madrid, Editorial Noesis.

VALBUENA DE LA FUENTE, Felicísimo (2006): Éric Berne, teórico de la comunicación. Madrid, Edipo.

\section{Pedro AGUILAR SERRANO}

Universidad Nacional de Educación a Distancia (UNED)

Profesor Tutor, Centro Asociado de Guadalajara

pedroaguilarserrano@gmail.com 